\title{
Prologue
}

ON PURPOSE

This book is about the rights of Indian tribes on tribal reservations. It is addressed to a great riddle: the political relationship between these sovereign American tribes and the other sovereign American government, that is, the government of the United States. We will not consider the rights of the individual Indians, as members of tribal governments or the national government, except where the nature of these individual rights elucidates the political status of tribes collectively.

Indian tribes are a common mental experience and natural fact for most Indians. Birth into a family, a territory, a spiritual world, and a race is a fact, but it is less significant than the mental experience that tribal people share. The essence of this mental experience is a world view-a warm, deep and lasting communal bond among all things in nature in a common vision of their proper relationship. This consciousness cements a collective culture that has proved resilient in modern society. Among members of the community it assumes the form of an interpersonal spiritual communion which has never been and may never be destroyed by outside forces. It continues to be the center of the tribal circle-the foundation of the whispering ideology of tribalism in this land. In combination with the 
natural fact of birth into a tribe, it has always kept tribal government the hope and road for the future of Indian people.

In the face of fickle federal policy, war and genocide, tribes have endured on the strength of their common experience. The community has at times resembled the scattering trees of a storm-swept prairie, but, with the aid of an unbroken communion with their ancestors' spirits, Indian people have never allowed their tribes to perish. Tribalism has always been the Road, that is, the heart and spirit of the Indian people. Tribalism is not an association of interest but a form of consciousness which faithfully reflects the experience of Indians. It is a normative system. The entire history of the federal relationship with tribes is a history of attempts to subvert this consciousness and replace it with the naked, alienated individualism and formal equality of contemporary American society. Indian people have resisted and endured, but the poverty and hate which follow upon failure to assimilate obligingly into the American "melting pot" are the high price they have paid for it. Indeed, poverty is ample evidence that mere communal property interests are not the glue that binds the tribal fabric, as some have argued.

The precise legal status of Indian tribes remains a source of confusion. Fundamental to this confusion is the basic fact of the survival of tribes as the only consensual government of Indian people-a fact which defies the anticipated disintegration of tribes and submersion of tribal Indians in white society. The legacy of judicial principles, rules and assumptions devised by the other government in the nineteenth century to explain the tribal-federal relationship was predicated on a theory of inevitable political evolution from "primitive" tribalism to "civilized" society. The Tribe, as a form of organization, was supposed to be as vanishing as the buffalo. Although Indian tribes have survived, notwithstanding a century of coercive government intervention, the legal system appears content to quibble over the details of the old rules rather than abandon them. The more the American courts strive to resolve tribal status from precedental principles, the more their opinions cast doubt upon the meaningfulness of the legal legacy.

In constitutional law today, the United States is a tripartite society. The citizens of the states enjoy all of the personal (or civil) and political liberties afforded by our system of delegated and limited powers. The residents of the territories and possessions are somewhat less secure, 
because in theory their political franchise may be altered, or even extinguished, if Congress chooses. Citizens of Indian tribes, by contrast, have little civil or political liberty. Their use of property is completely regulated, they are subject to separate laws and administration, and their self-governing powers have been altered at Congress's pleasure. No direct challenge to the constitutionality of this division has been heard in the Supreme Court for sixty years.

The current situation of tribal members evokes the whole course of political liberty in American history. While eminent jurists have attempted to brush the issue aside by referring to it as "unique" or "anomalous," it is in reality as fundamental and ancient as the existence of human society. It is the same issue that sparked the colonists to rebel against the British empire: the legitimacy of subordinating a community's economic and political rights to the pleasure of a powerful majority. In this respect, tribal citizens stand in the same position today as the colonists did in 1776.

The significance of this similarity lies in the fact that the architecture of the Constitution was intended to prevent a recurrence of the tyranny suffered by the colonies. The framers of the Constitution sought to accomplish their purpose by establishing a perpetual, dynamic equilibrium between central and local powers. Participation of all the people on both sides of this balance was expected to check accumulations of power by the few. However, as American society adjusted to the reality, unanticipated by the framers, of coexistence with Indian tribes, these essential requirements of political liberty were forgotten. A euphoria of national greatness blurred the vision of a road of political liberty which began in the colonial experience, and replaced this vision with submission to the law of economic expediency.

To us, political liberty means an effective voice in national government, and the right of the people to establish local governments to exercise any or all of the powers they have reserved to themselves. By this test, Indian tribes and tribal citizens have been systematically deprived of their constitutional rights for at least one hundred years. In the succeeding chapters we will attempt to define the constitutional guarantee of political liberty more fully, to explain the historical process by which tribal citizens have come to be deprived of their political liberty, and to develop a conceptual strategy for legal restoration of their right to a government of their choice. By not breaking completely with the deeper layers of American 
constitutional jurisprudence, we hope to transform, rather than negate, the consciousness of non-Indian Americans and preserve the continuity of both tribal and national government.

\section{ON METHOD}

We will often have recourse in the chapters that follow to matters of historical causality, but merely as a point of departure. The use of history is always fraught with difficulties and limitations. Law and history have a certain similitude in social theory. Lawyers seek evidence of the future in past events. Charles Miller, a historian, has written in his book, The Supreme Court and the Uses of History:

$[\mathrm{H}]$ istory may be defined as that which, in the opinion of the Supreme Court, is . believed to be true about the past-about past facts and past thoughts. . . . For purposes of analysis it may again be divided into two categories: history internal to the law and history external to the law. This distinction, like many distinctions, is blurred at the boundaries but clear at the center. History internal to the law consists of precedents . . . and legal history. Legal history pertains to the history of legal terms and doctrines. ... Somewhere on the borderline between legal history, which is internal to the law, and general political history, which is external to the law, lies the history used in . . . litigation involving Indian tribes. In no other fields of public law does history play so decisive a role, a role and a decisiveness accepted by all parties to the litigation as well as the court. ${ }^{1}$

Professor Miller may have overstated the point when he referred to "all parties." Indian tribes have usually disagreed with the history invoked in the course of particular disputes, yet Miller concludes that "beyond an appeal to conscience and legal documents the best evidence in most Indian cases is the testimony of history, especially the use, possession, practice and expectations concerning the lands."2 This has proved the tribes' undoing. It is important to bear in mind the differences between general history which "includes political, social, economic and cultural history,"3 and may be understood as empirical reality, and borderline history, which may be described as institutionalized or conventionalized reality.

The use of borderline history by the federal courts poses profound

1. Charles Miller, The Supreme Court and the Uses of History 24 (Cambridge, Mass.: 1969).

2. Id.

3. Id. 25. 
problems in legal method for tribal advocates. The main problem is that it vindicates past generations of lawyers' subjective selections of facts, and receives new facts, whether historical or contemporary, only to the extent that they are familiar, that is, consistent with old facts. Every community of people holds in common a certain set of assumptions about reality, called a paradigm by the philosopher Thomas Kuhn. A paradigm is the shared conception of what is possible, the boundaries of acceptable inquiry, the list of limiting cases. ${ }^{4}$ Courts are a kind of community, and the set of past judicial actions-precedent-constrains future initiative. What judges have said before is accepted as probably true, fossilizing antiquated prejudices, poor judgment and personal idiosyncrasies. Legal theory supposes that precedent guarantees continuity, which we equate with justice, at least if it is fair to define justice as relative certainty of outcomes. But precedent makes it quite difficult for courts to alter their data even in the face of compelling evidence of injustice or absurdity. Tribes pay a particularly high price for judicial conservatism and judicial resistance to new ideas and information, because they are trapped, unlike others, by both precedents of law and precedents of fact. If the courts continue to accept nineteenth-century assumptions regarding the transitory nature of tribalism, their inquiry will continue to be too narrow to arrive at viable solutions tolerable to the Indian people. "One element of the past intrudes quite unnecessarily upon the present," laments Charles Curtis in his book Lions Under the Throne. "We try to make the most of the consequences of what our forefathers did, but there is no reason why we should feel we have to carry out their plans for us. Were they so wise they didn't need to know the facts?',5

Borderline history is biased history. The legal legacy does not conform either to modern historical scholarship or to the continuing existence of tribalism. The accumulation of past doctrines, policies and practices designed to accelerate tribal disintegration has become the reality of the legal system. Past comments of judges are accepted over facts which illustrate the failure of their expectations to materialize in society. These conditions might be bearable if they lent certainty and consistency to tribal affairs, in keeping with the jurisprudential justification of the use of

4. Thomas Kuhn, The Structure of Scientific Revolutions 43 (2nd ed. Chicago: 1970).

5. Charles Curtis, Jr., Lions Under the Throne 2 (Boston: 1947). 
precedent. Unfortunately, as we will demonstrate, uncertainty plagues the law of tribal status, because the judges are slaves of a borderline history now grown so complex that few if any are aware of it all, and fewer still can recognize its accumulating self-contradictions. Our objective, then, must be to replace borderline history with elementary constitutional principles: to replace an artificial history that conceals false assumptions and unacceptable values with an explicit normative framework more consistent with general American political philosophy.

The remarkable thing about the conventional wisdom of tribal political status is its self-contradiction. If we are to believe the United States Supreme Court, the only general principle of tribal-federal law is that there are no general principles. ${ }^{6}$ We believe this to be false. General principles can be constructed to rationalize the status of tribes. Admittedly, such principles cannot be slavishly deduced from legal history. This is obvious: a judiciary convinced that there can be no generalities creates none. It has thus been necessary for us to go beyond rigorous legal analysis and examine the inconsistencies between our social ideals and law, politics and administration. We have concluded that a new conceptualization of the federal-tribal relationship, which we call the federal-tribal compact or treaty federalism, is necessary to reconcile the status of tribes with American society's essential social and political values.

The current ideological situation is dangerous. Courts' denial of general principles increases their opportunities to act capriciously. This represents, in fact, one of those inconsistencies between general American ideals and the law of tribes. Common law embodies the use of the precedent because we value consistency and equate it with justice. What is the logic of the exception for tribes? To reconcile this problem, lawyers have expended much paper and ink learnedly struggling to discover some elegant and hitherto obscure common denominator among the courts' products. Like medieval theologians, they avoid confrontation with their system's fatal paradoxes by immersing their thoughts in trivial comparisons and nice distinctions. We do not believe that there exists some subtle logic by which the apparent negation of American political values in tribal affairs can be made to disappear. Our approach has therefore been to construct a principle, sufficiently agreeable to the legacy of familiar case law to be intellectually acceptable, yet so freed from historical constraints and 
technical distinctions as to be capable of providing an understandable and practical guide for future conduct.

In other areas of constitutional litigation, historians and lawyers are equally reluctant to concede the legitimacy of the past as a source of new institutions. In fact, although the framers of the Constitution themselves studied history to detect the political errors of the past and avoid them in the future, they did not conceive of themselves as limited by precedent. ${ }^{7}$ They compared notes on the Iroquois Confederacy and classical republics, and argued the relative merits of the Swiss cantons and Dutch StatesGeneral, but did not pretend that the whole range of legitimate possibility for the new nation could be so discovered. As Alexander Hamilton observed, "the sacred rights of mankind are not to be rummaged for among old parchments or musty records." 8 Americans criticized those English jurists who "sought to establish right by appeal to precedent and to an unbroken tradition evolving from time immemorial, and . . . assumed . . . that the accumulation of the ages, the burden of inherited custom, contained within it a greater wisdom than any man or group of men could devise by the power of reason.",

The American Constitution does in fact embody much earlier law, especially the English Bill of Rights. At the same time its draftsmen recognized that they confronted difficulties unknown to the ancients or to their own European ancestors. As scholars they were capable of drawing upon history and science as tools to deduce appropriate new forms of government with reasonable hope for success, relying on observable similarities in causes and effects. But as politicians they had to communicate the wisdom and desirability of the scheme ultimately arrived at to a suspicious public, educated to different institutions and ideals. To break the shackles of political dogma and familiarity with old institutions, they distilled and disseminated a new framework of political analysis, hoping thereby to bring the people to speak a political language less hostile to the institutions they proposed for ratification.

7. Pauline Maier, From Resistance to Revolution 44, 289 (New York: 1972). Ezra Stiles advised "Men of Genius and penetrat[in]g Observation [to] take a large and Comprehensive View of the polities of the States and Countries around the Globe," including the "Lights of Orientals and Asiatics of the World itself both in ancient and modem Ages' (id. 290).

8. Bernard Bailyn, The Ideological Origins of the American Revolution 188 (Cambridge, Mass.: 1967).

9. Id. 33. To Americans of 1776 government was, in the words of "Cato," " a mere Piece of Clockwork," to be designed to "move to the publick Advantage" (Maier, From Resistance to Revolution 289). 
Like the reconceptualization in this book, the original theory of the Constitution was not solely the product of empirical scholarship. It was philosophy, and that was indispensible. "The Revolution," after all, John Adams would later write, "was in the minds of the people."10 As the philosophers of science have observed, empirical knowledge accumulates constantly, but real change does not occur until a new framework of analysis is discovered. ${ }^{11}$ Systems of knowledge, even the exact sciences, tend to become dogmatic because they rely upon old ideas to analyze new events. In the social sciences the problem is complicated by the subtle interrelationships of different disciplines, such that the dogmatic assumptions of each tend to prove the truth of all the others. When inconsistencies accumulate beyond reasonable toleration, a new system must be organized to reconcile old and new knowledge. This is a qualitative leap, a leap of faith. It is an act of intellectual transcendence. Only by transcending the integration of knowledge and ideas do we find, in Roberto Unger's metaphor, "the key that will allow us to escape from the prison-house, just as it was the chain with which the gates were long ago locked by the builders." 12

If conceptualization is a prison house, it can only be broken by reconceptualization. However, scholars strive hard to confine themselves to "certain technical riddles notable for their remoteness from our concern with understanding and transformation of society." 13 We have endeavored to analyze and reconceptualize, to transcend the conventional dogma of our field of study and introduce an alternative framework of analysis. We will undoubtedly be criticized for painting too broadly with the brush of imagination. We do not apologize. All law and social theory represent efforts to rationalize an irrational world full of inconsistency and uncertainties. At the margin, the choice among rationalizations is a matter of meaningfulness, not empirical demonstration, a matter of consistency with

10. Bailyn, Ideological Origins 1. Governor Pownall's great treatise, The Administration of the British Colonies (5th ed. London: 1774), described the English common law as "nothing more but the practice and determination of the courts on points of law, drawn into precedents; where the circumstances of a country and people, and their relation to the statutes and common law differ so greatly [as in America]; the common law of these countries must, in its natural course, become different, and sometimes even contrary, or at least incompatible, with the common law of England" ( 1 id. 105).

11. Kuhn, Scientific Revolutions 43.

12. Roberto Mangabeira Unger, Knowledge and Politics 4 (Chicago: 1975).

13. Id. 
consciousness. The English conservatives who concluded from their failure to show the colonists their "error" that all Americans were fools, failed to realize that the "obviousness" of their arguments was a product of nothing more than consistency with their own experience. Pauline Maier has observed that, in the end, the American Revolution became possible because Americans lost their empathy-what we have called a common experience-with other Britons. ${ }^{14}$ They could no longer accept being "a free and a great people together," as Jefferson put it. ${ }^{15}$ Our goal has been to arrive at a conceptualization consistent with the experience of both tribal and nontribal citizens. If we have succeeded, it may provide the Road for political reconciliation.

14. Maier, From Resistance to Revolution 269-70.

15. Id. 268. 
